\title{
SPATIAL CONCENTRATION OF BIOECONOMY SECTORS IN POLAND
}

Jaroslaw Golebiewski ${ }^{1}$, PhD hab., prof. WULS

${ }^{1}$ Warsaw University of Life Sciences, Faculty of Economic Sciences, Poland

\begin{abstract}
The problem discussed in the study is regional distribution of main sectors of bioeconomy in Poland and assessment of the level of their spatial concentration. The regional structure was analysed according to province. The statistical measures used to determine the level of geographic concentration and location included the location quotient and Gini concentration coefficient. The study was conducted in years 2011-2016. It was found that in years 2001-2016, the pace of structural changes in regions was not high indicating a high level of concentration of food industry production and agricultural commodity production. Analysis of location quotients in food processing indicates that the highest share of production sold in total food production was recorded in Mazowieckie, Wielkopolskie and Podlaskie provinces (location quotients of 1.5 to 2.0). In terms of agricultural production, the highest levels of agricultural commodity production have been recorded in Wielkopolskie and Podlaskie provinces (location quotient values of 1.5-2.2). The study has shown that the level of concentration of production in forestry in Poland has been stable, and deconcentration of production of renewable energy is progressing.
\end{abstract}

Key words: bioeconomy, concentration, agriculture production.

JEL code: Q13, P18

\section{Introduction}

Bioeconomy encompasses production of renewable biological resources and transformation of these resources and waste streams into value-added products, such as food, fodder, biological products and bioenergy. This approach to bioeconomy was formulated in the strategy of the European Commission, adapted in 2012, entitled "Innovating for sustainable growth: a bioeconomy for Europe" (COM, 2012). According to this definition, bioeconomy combines various sectors of economy that produce, process and re-use renewable biological resources (Maciejczak M., Hofreiter, K., 2013). These include farming, forestry, fishing, food production, manufacturing of bioderivative chemical substances and materials and bioenergy production. Development of these sectors is of key importance for tackling societal challenges, such as growing demand for food, climate changes and reduction in availability of fossil resources (Adamowicz M., 2017).

The main problem discussed in the study is regional distribution of main sectors of bioeconomy in Poland and assessment of the level of their geographic concentration. Economic literature offers many studies, analysing the spatial location of various sectors of economy (Leslie D., Reimer S., 1999; Cohena J.P., Paul C.J.M., 2005; Antonowicz P., 2014). The issue is becoming increasingly important in Poland as well, since transformation to market economy in the 1990s and the processes of integration with the EU have changed the structure of industry, also influencing changes in production location. The same applies to activity in the field known as bioeconomy. Building of effective strategies for development of bioeconomy requires recognition and analysis of spatial issues.

The aim of the study is to determine the spatial distribution of main sectors of bioeconomy in Poland according to region (province) and to assess the level and direction of changes in their spatial concentration. Various statistical measures will be applied to assess the geographic concentration and location, such as the location quotient and Gini concentration coefficient.

The analysis encompassed four main sectors of economy: farming, forestry, food processing and bioenergy production. For these sectors, the data collected included commodity production in PLN million (farming), timber harvesting in thousand $\mathrm{m}^{3}$ (forestry), production sold in PLN million 
(food processing) and production of renewable energy in $\mathrm{GWh}^{1}$. The reference variable for determination of location and concentration coefficient was the population number. Data were obtained from the Local Data Bank of the Central Statistical Office. The time span for the study included years 2011-2016.

The structure of the article is as follows. The first part presents a short literature review, focusing mainly on the key theoretical aspects of bioeconomy, followed by results of an empirical study of geographical concentration. The second part presents the research methodology applied. The third part contains results of empirical research on geographical concentration of bioeconomy in Poland. The last part of the study presents some final remarks.

\section{Theory and empirical studies of spatial concentration}

Theoretical models and empirical studies of regional concentration have been developed for a long time. At present, the theoretical and practical reasons for studying spatial concentration are rooted in three main fields of research in theory of economics, that is: the neoclassical theory, the new trade theory and the new economic geography (NEG) (Aiginger K., Rossi-Hansberg E., 2006). The neoclassical theory assumes that there are differences in productivity between regions, and liberalization of trade and increase in economic integration results in relocation of production and increased specialization to achieve a competitive advantage. The neoclassical models assume ideal competition, uniformity of products and lack of increase in the economies of scale. Location is determined exogenously, on the basis of inherited spatial distribution of natural resources, technologies and/or production factors Economic activity disperses or concentrates in space, following the pattern of dispersion or concentration of these basic exogenous features. The dominant location pattern is inter-branch specialization: production takes place in those locations, which are characterized by a comparative advantage. Within such framework, assuming zero costs of trade, spatial distribution of demand influences the structure of trade, but not location of production. Assuming that there are trade costs, and in a situation, in which demand is distributed more evenly in space in comparison with production resources, higher trade costs lead to greater dispersion of activity. Limited trade costs result in an ideal dispersion of industry branches according to geographic distribution of demand. Thus, reduction of trade costs generates a trend of increasing of the degree of specialization (Jasinski L.J., 2008).

The new theory of international trade, developed mainly by Paul Krugman ${ }^{2}$, is partially rooted and partially opposed to the theory of comparative advantage, developed by David Ricardo in the early 19th century and modified in the mid-20th century by Eli Heckshcher and Bertil Ohlin (Michalek J.J., 2013). Development of international trade in commodities in the late 20th century undermined the theories of both Swedish economists, enforcing a significant change in the interpretation. One of the key reasons for low predictive power of the $\mathrm{H}-\mathrm{O}$ theory is the growing intra-industry trade, observed since the mid-1960s. This trade, which consists of simultaneous export and import in the same sectors or branches of production, increased mainly between highly developed countries, characterized by a similar relative level of productivity factors. This theory is based on assumptions very different from those forming the neoclassical theory. It assumes that products are horizontally diversified, which means that every product is available in many varieties. In accordance with the Dixit-Stiglitz demand function, it assumes that the growing number of

\footnotetext{
${ }^{1}$ Due to lack of regional data on bioenergy production, the study was based on renewable energy production data. In Poland, the share of bioenergy in the renewable energy structure in 2014 amounted to $88.9 \%$.

2 P. Krugman received a Nobel prize in 2008 for the new trade theory, presented in the article: Increasing Returns to Scale, Monopolistic Competition, and International Trade (1979), and for his contribution to theory of location of business activity, rooted in the new theory of trade.
} 
varieties in specific goods results in growing consumer satisfaction. On the supply side, Krugman assumed the existence of the economies of scale, like in most modern branches of industry. Increasing of production scale reduces the average production cost, thus improving competitiveness of companies. Growing revenues of scale are usually associated with imperfect competition. Krugman's model provides for the so-called perfect monopolistic competition (Chamberlin's model), in which every company is a monopolist in production of a single variety of a given commodity, while the freedom of entering and leaving the market eliminates extraordinary profits and the prices are equal to average production costs. Each of identical companies produces a different variety of the same commodity. The only production factor is the labour force, which lacks international mobility, allowing for creation of a market balance in a given country. Thanks to these assumptions, Krugman proved the possibility of emergence of intra-industry trade, based on horizontally diversified products, between countries characterized by a very similar, high level of development (Krugman P., 1979). Such trade contributes to increasing of the number of varieties of individual goods and thus - to reduction of prices of goods available on the market. The result is growing wealth of the societies engaged in trade. This is possible thanks to increasing of the production scale and reduction of prices and a growth in the number of varieties of goods available on the common, liberalized market (Bartkowiak R., 2010).

The issue of spatial concentration also refers to the field of economic geography. In the new economic geography (NEG), the significance of geographic factors in management is assigned a key role, while regional specialization is a result of spatial agglomeration of economic activity.

Economic geography is a field of knowledge, searching for answers to questions concerning the causes of distribution of the available productivity factor resources (mainly capital and labour) between countries and regions. P. Krugman used it along with such terms as the economies of scale, consumer's preference for variety and transport cost. From his perspective, consumers (and employees at the same time) prefer to settle in locations, which are densely populated, where they can expect higher real wages thanks to the economies of scale (Krugman P., 1998). On the other hand, the factor, which is decisive for capital distribution, is comparison of economies of scale with costs of transport of goods. Correlations between the two shape the processes of concentration and deconcentration of business activity. Emergence of the big urban agglomerations is to be caused by advantage of the economies of scale over the costs of transport. An opposite situation contributes to more even distribution of labour and capital resources. Economic geography also uses the core and periphery model (Krugman P., 1991). More than one half of the global population lives in cities, which are often very big, constituting the core; the minority lives in the rural areas, or the periphery. The factor decisive for growth of the core are, once again, advantages of uniting production in a single location (Jasinski L.J., 2008).

The theoretical premises have served as a basis for numerous studies dedicated to the phenomena of regional concentration and specialization (Maslikhina V., 2017; Niepmann F., Felbermay G.J., 2010; Martin P. et al., 2011). These also have dealt with bioeconomy sectors. Most of these studies have compared countries in a given region, such as the European Union, or provinces (regions) within the borders of individual countries. An in-depth analysis of the state of bioeconomy in the EU has been provided in a report prepared in 2016 (Ronzon T., et al. 2017). The report also assesses the distribution of bioeconomy locations in the EU member states. The location quotient served as a basis for assessment of distribution of employment and revenues from sale in all sectors of bioeconomy. The report states that Romania seems to be the most specialized EU 
member state with regard to bioeconomy, with the location quotient of 3.9. This means that the share of persons working in the Romanian biosector is almost four times higher than the average share of persons working in 28 member states of the EU. In reality, this "concentration" in bioeconomy is caused mainly by very high concentration of the Romanian labour market in agriculture. In 2014, 28 \% people working in Romania were employed in the agricultural sector, and $83 \%$ of people in Romanian bioeconomy worked in agriculture. High location quotients for bioeconomy were also recorded in Bulgaria, Croatia, Greece, Poland, Portugal, Latvia, Lithuania and Slovenia (1.5 to 2.1). In these countries, the high share of bioeconomy was also due to employment in agriculture. In the remaining part of the EU, bioeconomy location quotient values range from 0.4 to 1.3. The labour market in these Member States is not concentrated, in particular, on bioeconomy, although some specific sub-sectors of bioeconomy indicate high location quotients. For instance, Cyprus shows a very high location quotient in the sector of fishing and aquaculture. Estonia concentrates on forestry and production of timber components. Fishing and aquaculture are also a developed labour market in Estonia (Ronzon, T., et al., 2017).

A detailed analysis of the strategy of research and innovations in bioeconomy at the regional level can also be found in the report Bioeconomy development in EU regions. This regional study shows that research and innovation associated with bioeconomy (R\&I) is a priority for most European countries and regions in the period of 2014-2020. Among 210 territorial units analysed (EU regions and countries), 207 (98.6\%) take the aspects associated with bioeconomy into account in their priorities and plans in the field of research and innovation. Nevertheless, bioeconomy at the regional level is very diversified. According to the authors of the report, implementation of bioeconomy at the regional level in the EU thus requires a more detailed analysis and in-depth understanding of various regional characteristics, needs and potential (Haarich S., 2017).

One of the basic sectors of bioeconomy in the EU and in Poland is the food industry. Innovation is a significant aspect of development of this sector. An in-depth analysis of concentration of expenditures for innovation in the food industry in Poland in years 2005-2011 at the regional level has been presented by Grzybowska. This author has found that the structure of expenditures from the interregional perspective is a dichotomous one: one half represents the expenditures of Mazowieckie and Wielkopolskie provinces, and the other half - those of the remaining regions. (Grzybowska B., 2013).

\section{Statistical measures of spatial concentration}

Analysis of spatial distribution is associated with the problem of equivalence of observations. Most often, the set of regions analysed is made up of administrative (geographic) areas, which differ in terms of their area or population. In order to mitigate the effect of diversified region size, and to conduct analysis under the conditions of comparability of observations, weight variables are used in spatial analyses. As a result of application of weight variables, spatial distribution of the variable is not analysed in isolation, but compared with distribution of the weight variable. It is assumed that a given phenomenon is strongly concentrated, if the examined and weight variable distributions differ significantly. In this study, the number of inhabitants was used as the weight variable. The key measure used in analysis of spatial distribution of economic phenomena is the location quotient. The location quotient is calculated separately for each of the regions examined 
(Suchecki B., 2010). The following formula for determination of the location quotient has been applied in the study:

$$
L Q_{r}^{i}=\frac{U_{r}^{i}}{W_{r}}
$$

Where:

$Q_{r}^{i}$ - location quotient

$u_{r}^{i}$ - the share of $r$-th region in the set of all regions for the aggregate variable analysed

$u_{r} i$ - the share of $r$-th region in the set of all regions for the weight variable

The $L Q$ is to be used to assess regional diversification of production size in four sectors of bioeconomy in relation to the number of inhabitants in a given region.

The synthetic measure of concentration, applied in this study, based on the Lorenz curve, is the Gini coefficient (Suchecki, 2010). The following formula was applied to determine its value in the study, taking into account the spatial weights:

$$
G_{i}^{*}=1-\sum_{r=1: k=0}^{R}\left[v_{r(k+1)}-v_{r(k)}\right]\left[\lambda_{r(k+1)}^{i+\lambda^{i}} r(k)\right]
$$

Where:

$G_{i}^{*}-$ Gini index

$v_{r(k)}$ - accumulated share of weight variable

$\lambda_{r(k)}^{i}$ - accumulated values of examined variable

$r, k=1,2, \ldots, r$

Gini coefficient was used to assess changes in the level of geographic concentration in four sectors of bioeconomy in years 2011-2016.

\section{Research results and discussion Test results}

Analysis of distribution of production in the key sectors of bioeconomy was conducted on the basis of data of the Central Statistical Office, using various production measures. For agriculture, the commodity production measure in PLN million was used; distribution of production in forestry was measured on the basis of timber production in thousands of cubic meters, food processing production was assessed on the basis of production sold in PLN million, while production of renewable energy was measured in terms of energy production in GWh. The quantitative data collected for production sizes in basic sectors of bioeconomy according to region has been presented in Table 1.

Data presented in table 1 indicates that the regions examined differ in terms of population. The smallest provinces are: Opolskie, Lubuskie, Podlaskie and Swietokrzyskie. The biggest provinces in terms of population are: Malopolskie, Wielkopolskie, Slaskie and Mazowieckie. The share of the biggest four provinces amounted to $44 \%$ of the country population.

The table also presents regional distribution of agricultural production, forestry, food industry and renewable energy. In agricultural production, the highest share was recorded in Podlaskie, Lubelskie, Kujawsko-pomorskie, Lodzkie, Mazowieckie and Wielkopolskie provinces. The share of these six provinces represented $66 \%$ of agricultural commodity production in the country. Timber production in Poland is dominated by Lubelskie, Wielkopolskie i Warminsko-mazurskie and 
Zachodniopomorskie provinces, with the share reaching almost $40 \%$. $54 \%$ of total food production takes place in the following provinces: Slaskie, Lodzkie, Wielkopolskie and Mazowieckie. On the other hand, renewable energy production takes place mainly in Pomorskie, Swietokrzyskie, Kujawsko-pomorskie and Zachodniopomorskie provinces (representing $51 \%$ of total timber production).

Table 1

The size and structure of production in bioeconomy and population according to province in 2016

\begin{tabular}{|l|r|r|r|r|r|r|r|r|r|c|}
\hline \multicolumn{1}{|c|}{ Voivodeship } & \multicolumn{1}{c|}{ POP } & \% & PTR** & \% & PD & \% & PAS & \% & PEO & \% \\
\hline Dolnoslaskie & 2903710 & 8 & 3518 & 4 & 3364.8 & 8 & 6041 & 3 & 708 & 3 \\
\hline Kujawsko-pomorskie & 2083927 & 5 & 6177 & 8 & 1922.4 & 5 & 12923 & 6 & 3091 & 14 \\
\hline Lubelskie & 2133340 & 6 & 6163 & 8 & 1999.5 & 5 & 7316 & 4 & 445 & 2 \\
\hline Lubuskie & 1017376 & 3 & 1843 & 2 & 3572.7 & 9 & 2925 & 1 & 632 & 3 \\
\hline Lodzkie & 2485323 & 6 & 6427 & 8 & 1322.9 & 3 & 16512 & 8 & 1411 & 6 \\
\hline Malopolskie & 3382260 & 9 & 2426 & 3 & 1364.4 & 3 & 13256 & 7 & 491 & 2 \\
\hline Mazowieckie & 5365898 & 14 & 13603 & 17 & 2416.5 & 6 & 45931 & 23 & 1437 & 6 \\
\hline Opolskie & 993036 & 3 & 2462 & 3 & 1426.5 & 3 & 4391 & 2 & 591 & 3 \\
\hline Podkarpackie & 2127656 & 6 & 1521 & 2 & 2559.0 & 6 & 3152 & 2 & 653 & 3 \\
\hline Podlaskie & 1186625 & 3 & 5229 & 7 & 2184.8 & 5 & 12103 & 6 & 815 & 4 \\
\hline Pomorskie & 2315611 & 6 & 3607 & 5 & 3346.3 & 8 & 12146 & 6 & 2226 & 10 \\
\hline Slaskie & 4559164 & 12 & 2264 & 3 & 1790.9 & 4 & 15272 & 8 & 1118 & 5 \\
\hline Swietokrzyskie & 1252900 & 3 & 2558 & 3 & 1340.4 & 3 & 3357 & 2 & 2343 & 10 \\
\hline Warminsko-mazurskie & 1436367 & 4 & 4233 & 5 & 3834.1 & 9 & 11243 & 6 & 976 & 4 \\
\hline Wielkopolskie & 3481625 & 9 & 14873 & 19 & 3672.7 & 9 & 31028 & 15 & 1977 & 9 \\
\hline Zachodniopomorskie & 1708174 & 4 & 2940 & 4 & 4783.0 & 12 & 5601 & 3 & 3912 & 17 \\
\hline Poland & 38432992 & 100 & 79844 & 100 & 40900.7 & 100 & 203197 & 100 & 22825 & 100 \\
\hline FOP Population,
\end{tabular}

* POP - Population, PTR - Agricultural commodity production ( $\mathrm{m} / \mathrm{n}$ zl), PD-Obtaining wood (thou $\mathrm{m}^{3}$ ), PAS - Sold production of the food industry ( $\mathrm{mln}$ zl), PEO - Renewable energy production (GWh).

** Agricultural commodity production - data in 2015

Source: author's calculation based on Local data bank

On the basis of production size in individual sectors, taking into account the population data, the location quotient values were determined. Detailed data can be found in Table 2. Agricultural production is the main sector of bioeconomy, responsible for supply of biomass in form of agricultural raw materials (Drejerska N., Golebiewski J., 2017). Products manufactured in agriculture are used for food production by the food industry, as well as for production of energy and various types of raw materials. Analysis of location quotients for agricultural commodity production in regions indicates that the lowest level of production has been recorded in Slaskie, Podkarpackie and Malopolskie provinces.

The location quotient values range from 0.2 to 0.49 in these regions. This means that agricultural production of this region represents a relatively low share in total agricultural production. The highest levels of agricultural commodity production have been recorded in Wielkopolskie and Podlaskie provinces (location quotient values of 1.5-2.2). These regions are characterized by modern, intensive farming, including, in particular, well developed animal production.

The second sector of bioeconomy analyzed is forestry. It is also one of the main producers of biomass, used by many other sectors of economy. Timber is the main product of forestry. It is used in construction, paper making, furniture production, and it is a significant raw material in energy production. The highest location quotients for timber production were recorded in Podlaskie and 
Warminsko-mazurskie provinces in the north-eastern part of the country and Zachodniopomorskie and Lubuskie provinces in the west. The lowest location quotients for timber production in 2016 were recorded in Slaskie, Malopolskie, Mazowieckie and Lodzkie provinces.

Location quotients for agricultural commodity production, forestry, the food industry and renewable energy in 2016

\begin{tabular}{|l|c|c|c|c|}
\hline \multicolumn{1}{|c|}{ Voivodeship } & $\begin{array}{c}\text { Agricultural } \\
\text { commodity } \\
\text { production }\end{array}$ & Obtaining wood & $\begin{array}{c}\text { Sold production of } \\
\text { the food industry }\end{array}$ & $\begin{array}{c}\text { Renewable } \\
\text { energy } \\
\text { production }\end{array}$ \\
\hline Dolnoslaskie & $\mathbf{0 . 5 8 3}$ & $\mathbf{1 . 0 8 9}$ & $\mathbf{0 . 3 9 4}$ & $\mathbf{0 . 4 1 1}$ \\
\hline Kujawsko-pomorskie & 1.425 & 0.867 & 1.173 & 2.497 \\
\hline Lubelskie & 1.387 & 0.881 & 0.649 & 0.351 \\
\hline Lubuskie & 0.871 & 3.300 & 0.544 & 1.045 \\
\hline Lodzkie & 1.241 & 0.500 & 1.257 & 0.956 \\
\hline Malopolskie & 0.346 & 0.379 & 0.741 & 0.244 \\
\hline Mazowieckie & 1.224 & 0.423 & 1.619 & 0.451 \\
\hline Opolskie & 1.190 & 1.350 & 0.836 & 1.002 \\
\hline Podkarpackie & 0.344 & 1.130 & 0.280 & 0.517 \\
\hline Podlaskie & 2.117 & 1.730 & 1.929 & 1.157 \\
\hline Pomorskie & 0.753 & 1.358 & 0.992 & 1.618 \\
\hline Slaskie & 0.238 & 0.369 & 0.634 & 0.413 \\
\hline Swietokrzyskie & 0.980 & 1.005 & 0.507 & 3.149 \\
\hline $\begin{array}{l}\text { Warminsko- } \\
\text { mazurskie }\end{array}$ & 1.415 & 2.508 & 1.481 & 1.144 \\
\hline Wielkopolskie & 2.060 & 0.991 & 1.686 & 0.956 \\
\hline Zachodniopomorskie & 0.827 & 2.631 & 0.620 & 3.856 \\
\hline
\end{tabular}

Source: author's calculation based on Local data bank

Food processing is one of the most dynamically developing sectors of economy in Poland. In terms of bioeconomy, food processing engages in production of food items on the basis of agricultural raw materials. The industry includes processing of plant and animal products. Analysis of location quotients in food processing indicates that the highest share of production sold in total food production was recorded in Mazowieckie, Wielkopolskie and Podlaskie provinces (location quotients of 1.5 to 2.0). The lowest share in food processing, on the other hand, was recorded in Podkarpackie and Dolnoslaskie provinces.

Production of renewable energy is an important sector of bioeconomy. In some countries, production of electricity on the basis of renewable energy sources has exceeded $50 \%$. A good example here is Latvia, where the policy of support for development of power plants using biomass, the share of renewable energy sources in electricity production in 2014 exceeded $51 \%$ (Rubins M., Pilvere I., 2017).

Similar trends can be observed in Poland, where in years 2005-2015, production of bioenergy from agricultural forces increased from 5 to 42 TJ (Wicki L., 2017). Production of renewable energy in Poland is also characterized by great regional diversity. In year 2016, the highest location quotients were recorded in Pomorskie, Kujawsko-pomorskie, Swietokrzyskie and Zachodniopomorskie provinces. Production of renewable energy is developing mainly on the coast and in the central part of the country; installations of this kind are rarely found in the southern and eastern parts of Poland. This indicates existence of some regional conditions that shape development of renewable energy. 
The values of Gini coefficient, taking into account spatial weights for the analysed bioeconomy sectors, have been presented in Figure 1.

0,500

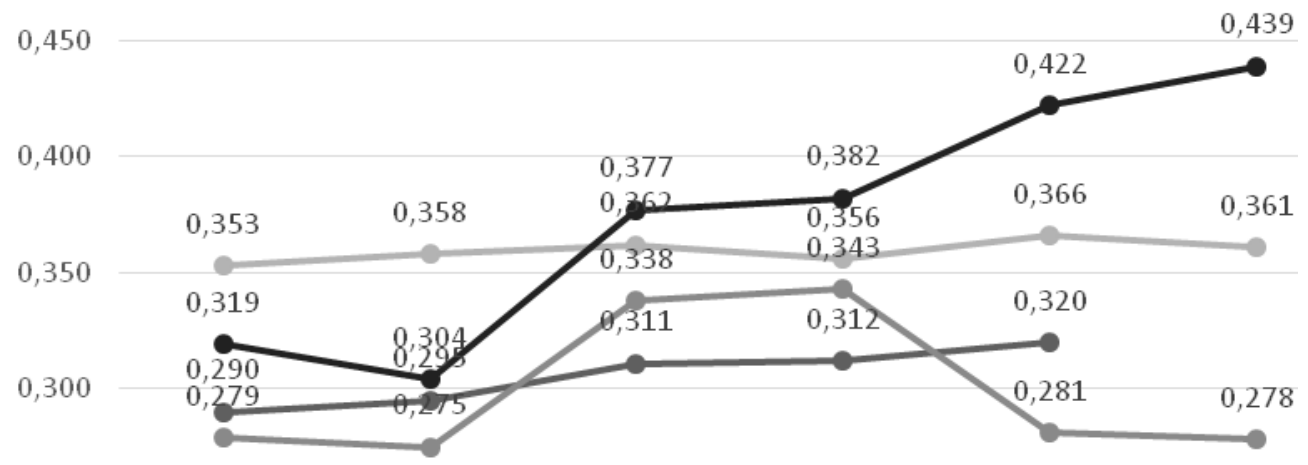

0,250

0,200

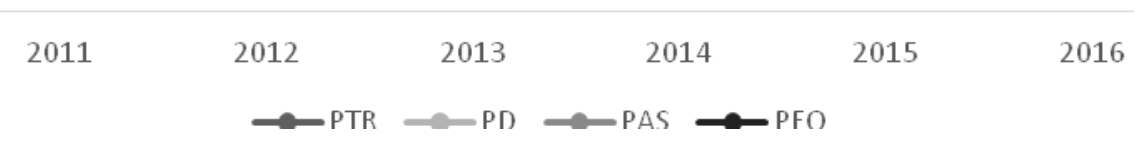

Source: author's calculation based on Local data bank

Fig. 1. Gini concentration coefficients for agricultural commodity production, timber production in forestry, food processing

In 2016, the highest levels of concentration were recorded for food processing (Gini coefficient of 0.278$)$. Agricultural production was only slightly less concentrated (0.320 - data for year 2015). The lowest level of geographical concentration was recorded for production of renewable energy (0.439).

\section{Summary}

Bioeconomy constitutes a significant component of the Polish and European economy. It is subject to market rules and principles. The conditions of functioning of enterprises in the global economy force managers to tackle new challenges with regard to selection of enterprise location. Poland, as a part of the global system, shows similar trends, including the phenomenon of spatial concentration of production.

The study depicts the issue of regional concentration of bioeconomy sectors. The study was developed using the basic statistical measures of concentration, that is, the location quotient and the Gini concentration coefficient.

The main results of the study indicate that in years 2001-2016, the pace of structural changes in regions was not high. A high level of concentration of food industry production and agricultural commodity production. Analysis of location quotients in food processing indicates that the highest share of production sold in total food production was recorded in Mazowieckie, Wielkopolskie and Podlaskie provinces (location quotients of 1.5 to 2.0). In terms of agricultural production, the highest levels of agricultural commodity production have been recorded in Wielkopolskie and Podlaskie provinces (location quotient values of 1.5-2.2). The study has shown that the level of concentration of production in forestry in Poland has been stable, and deconcentration of production of renewable energy is progressing. 
A significant and interesting issue in this context would be also to determine the driving forces behind regional concentration of bioeconomy in Poland. In-depth analyses, in terms of absolute and relative terms, should also be recommended, not only on the domestic scale, but also at the EU level.

\section{Bibliography}

1. Adamowicz, M. (2017). Bio-economy as an Element of Development Strategies in the European Union, Proceedings of the 2017 International Conference. Economic Science for Rural Development, 44, pp. 237-247.

2. Aiginger, K., Rossi-Hansberg, E. (2006). Specialization and Concentration: a Note on Theory and Evidence, Empirica, 33, pp. 225-266.

3. Antonowicz, P. (2014). Zastosowanie wspolczynnika lokalizacji LQ i krzywej koncentracji w badaniach nad przestrzennym zroznicowaniem upadlosci przedsiebiorstw w gospodarce (Studies on Location Quotient and Concentration Curve Applications of Bankruptcy Enterprises in the Economy), Journal of Management and Finance, 12(3/1), pp. 53-63.

4. Bartkowiak, R. (2010). Wspolczesne teorie ekonomiczne (Contemporary Economic Theories). Roczniki Nauk Rolniczych, SERIA G, 97(2).

5. Cohena, J. P., Paul, C. J. M. (2005). Agglomeration Economies and industry location decisions: the impacts of spatial and industrial spillovers, Regional Science and Urban Economics, 35, pp. 215-237.

6. COM (2012). Communication from the Commission to the European Parliament, the Council, the European Economic and Social Committee and the Committee of the Regions Innovating for Sustainable Growth: A Bioeconomy for Europe.

7. Drejerska N., Golebiewski J., (2017). The Role of Poland's Primary Sector in the Development of the Country's Bioeconomy, Rivista di Economia Agraria, Anno LXXII, n. 3, pp. 311-326.

8. Grzybowska, B. (2013). Przestrzenna koncentracja potencjalu innowacyjnego w przemysle spożywczym (Spatial Concentration of Innovative Potential in Food Industry), Roczniki Ekonomii Rolnictwa i Rozwoju Obszarow Wiejskich, 100(2), pp. 53-64.

9. Haarich, S. (2017). Bioeconomy development in EU regions. Final Report. Mapping of EU Member States Regions. Research and Innovation plans \& Strategies for Smart Specialisation (RIS3) on Bioeconomy. European Commission.

10. Jasinski, L. J. (2008). Nobel z ekonomii. Przeglad laureatow w zarysie (Nobel in Economics). Warszawa: Wydawnictwo Key Text.

11. Krugman, P. (1979). Increasing Returns, Monopolistic Competition, and International Trade, Journal of International Economics, 9, pp. 469-479.

12. Krugman, P. (1991). Increasing Returns and Economic Geography. The Journal of Political Economy, 99(3), pp. 483-499.

13. Krugman, P. (1998). What's New about the New Economic Geography? Oxford Review of Economic Policy, $14(2)$.

14. Leslie, D., Reimer, S. (1999). Spatializing Commodity Chains, Progress in Human Geography, 23(3), pp. 401-420.

15. Maciejczak, M.,Hofreiter, K. (2013). How to Define Bioeconomy? Roczniki Naukowe Stowarzyszenia Ekonomistow Rolnictwa i Agrobiznesu, XV(4). pp. 243-248.

16. Martin, P., Mayer, T., Mayneris, F. (2011). Spatial Concentration and Plant-level Productivity in France, Journal of Urban Economics, 69, pp. 182-195.

17. Maslikhina, V. (2017). Spatial Concentration of the Manufacturing Industry: Evidence from Russia, Journal of Applied Engineering Science, 15(4), pp. 509-517.

18. Michalek, J. J. (2013). Nowy nurt w teorii handlu miedzynarodowego i jego znaczenie dla analizy skutkow integracji walutowej w krajach Europy Srodkowo-Wschodniej. IX Kongres Ekonomistow Polskich.

19. Niepmann, F., Felbermay, G. J. (2010). Globalisation and the Spatial Concentration of Production, The World Economy, 33(5), pp. 680-709.

20. Ronzon, T., Lusser, M., Klinkenberg, M. (ed.), Landa, L., Lopez, J.S. (ed.), M'Barek, R., Hadjamu, G. (ed.), Belward, A. (ed.), Camia, A. (ed.), Giuntoli, J., Cristobal J., Parisi C., Ferrari E., Marelli, L., de Matos, C.T., Barbero M.G., Cerezo E.R. (2017). Bioeconomy Report 2016. JRC Scientific and Policy Report. EUR 28468 EN. DOI: $10.2760 / 20166$.

21. Rubins, M., Pilvere, I. (2017). Development of Renewable Energy Policy in Latvia, Proceedings of the 2017 International Conference. Economic Science for Rural Development, 44, pp. 281-291.

22. Suchecki, B. (2010). Ekonometria przestrzenna. Metody i modele analizy danych przestrzennych (Spatial Econometrics. Methods and models of spatial data analysis). Wydawnictwo C.H. Beck. Warszawa.

23. Wicki, L. (2017). Food and Bioenergy - Evidence from Poland, Proceedings of the 2017 International Conference Economic Science for Rural Development, 44, pp. 299-305. 